Chirurgia (2018) 113: 300-306

No. 3, May - June

Copyright@ Celsius

http://dx.doi.org/10.21614/chirurgia.113.3.300

\title{
Surgical Treatment of Chronic Pancreatitis: The State of the Art
}

\author{
Marius Kemper, Jakob R. Izbicki, Kai Bachmann
}

Department of General, Visceral and Thoracic Surgery, University Medical Centre Hamburg-Eppendorf, Hamburg, Germany

Corresponding author:

Marius Kemper, MD

Department of General Visceral

and Thoracic Surgery

University Medical Centre

Hamburg-Eppendorf

Martinistrasse 52, 20246 Hamburg

Germany

E-mail: m.kemper@uke.de

\section{Rezumat \\ Actualități în tratamentul chirurgical al pancreatitei cronice}

Pancreatita cronică este o boală comună însoțită de o morbiditate şi o mortalitate considerabilă. Complicațiile asociate pancreatitei cronice, cum ar fi pseudochisturile, stenoza structurilor anatomice adiacente sau durerea care nu pot fi tratate conservator, pot fi tratate chirurgical sau intervențional prin endoscopie. Chirurgia este superioară endoscopiei în ceea ce priveşte managementul durerii pe termen lung. Rezecția pancreatică cu conservarea duodenului este procedura chirurgicală de elecție la pacienții care prezintă modificări şi inflamații ale capului pancreasului. Cea mai bună sincronizare a intervenției chirurgicale, managementul perioperator standardizat este în centrul cercetării actuale.

Cuvinte cheie: chirurgie, pancreatită cronică, rezecție, procedură de drenaj, rezecția capul pancreatic cu conservarea duodenului, calitatea vieții 
pancreas. The best timing of surgery, the ideal standardized perioperative management are the focus of current research.

Key words: surgery, chronic pancreatitis, resection, drainage procedure, duodenum preserving resection of the pancreatic head, quality of life

\section{Introduction}

Chronic pancreatitis (CP) is a chronic inflammatory process leading to the destruction of and fibrotic changes in the pancreatic parenchyma. Over its progression the disease restricts the pancreas's exocrine function and in the late stage its endocrine function. In the United States, CP is the most common benign disease requiring hospitalization, emphasizing the socioeconomic significance of the disease (1).

While the precise pathophysiological mechanisms remain unclear, alcohol abuse is seen as an etiological factor (60-70\%). The critical limit is assumed to be the consumption of more than $80 \mathrm{~g}$ of alcohol per day over 6-12 years. Smoking promotes the progression of $\mathrm{CP}(2)$. An idiopathic genesis must be assumed in $10-30 \%$ of cases. Current studies suggest that a gene mutation in the cystic fibrosis transmembrane conductance regulator (CFTR) plays a role in the genesis of idiopathic pancreatitis. A mutation in the CFTR gene leads to a lower tolerance for alcohol $(3,4)$.

Belonging to the rare causes that are present $5 \%$ of cases are hyperparathyroidism, malignant obstruction of the pancreatic ductor by an intraductal papillary mucinous neoplasm (IPMN), overuse of analgesics, trauma and genetic predisposition. The causes of hereditary $\mathrm{CP}$ include cystic fibrosis and alpha-1antitrypsin deficiency (5-8). The autoimmune form of $\mathrm{CP}$ is associated with elevated levels of serum IgG and autoantibodies, and responds to steroids $(9,10)$.

The prognosis for $\mathrm{CP}$ depends on the severity of the disease, frequency of pain episodes, and existing complications. The characteristic complications are pancreatic pseudocysts which pose the risk of infection and rupture, pancreatic duct stricture, and duodenal stenosis. As the disease progresses, pancreatic ascites, malnutrition and chronic pain syndrome may occur. In addition, peptic ulcers, splenic vein and portal vein thromboses, and stenosis of the intrapancreatic bile duct may also occur. $\mathrm{CP}$ is a risk factor for pancreatic carcinoma (11).

Clinically, CP presents as an intermittent or persistent band-like pain in the upper abdomen radiating out into the back. For $80-85 \%$ of patients pain is the predominant clinical symptom $(13,14)$. Belonging to the pancreatogenic cases of the pain are the inflammatory infiltration of the parenchyma and the nerve sheaths, particularly of the sensitive nerves. Obstructing stones or stenosis can increase the intraductal and intraparenchymatous pressure. Exocrine insufficiency is characterized by steatorrhea and leads to malnutrition over time. Exocrine insufficiency occurs if secretion of the enzymes is reduced by more than $90-95 \%$ (15).

\section{Diagnostics}

Diagnosis of $\mathrm{CP}$ is based on clinical, laboratory and morphological imaging parameters. During the structured anamnesis, questions should be asked explicitly about alcohol consumption, weight loss, frequency and duration of the pain episodes, use of analgesics. Symptoms of endocrine and exocrine insufficiency, and a family history should be also recorded. Suitable as an indicator for quantifying pain and quality of life are the Izbicki pain score and the EORTC Quality of Life questionnaire resepectively (16).

The digestive enzymes lipase and amylase can be elevated in the blood. Likewise, in the case of bile duct compression, an increase in 
the cholestasis parameters is to be expected. In cases with a suspected autoimmune genesis, the determination of IgG and IgG4 is indicated (17). Where malignancies are suspected, tumor marker Ca-19-9 should be measured. Leukopenia or thrombocytopenia may be present in the case of splenic vein thrombosis.

Performing transabdominal sonography as a basic diagnostic measure is meaningful to clarify differential diagnoses. Among the imaging techniques available, endosonography (EUS) has been established has the most sensitive method. Where there are indistinct signs of pancreatitis (inhomogeneousorgan, normally wide pancreatic duct), endosonography with the option of endoscopic-guided fine needle aspiration (EUS-FNP) should be carried out (18). The CT imaging of the abdomen essential for planning surgical intervention enables precise imaging of the pancreatic parenchyma and detection of pancreatic pseudocysts. Another obligatory diagnostic measure prior to an intervention is an MRT including MRCP for detailed visualization of the pancreatic duct. Today, ERCP plays a role in differential diagnostics regarding autoimmune pancreatitis but is otherwise only used for therapy.

\section{Therapy}

The wide range of conservative, endoscopic, interventional and surgical treatment options requires an extremely high degree of interdisciplinary collaboration. Not only endoscopic therapy, but also surgical therapy for CP requires extensive technical and medical expertise and should therefore only be performed at specialized centers.

Where there are no approaches to address the cause of $\mathrm{CP}$, therapy is limited to managing the symptoms. The components of conservative therapy for uncomplicated cases of $\mathrm{CP}$ encompass sufficient analgesics, substitution of pancreatic enzymes, abstention from alcohol and nicotine, and optimized anti-diabetic therapy. Continued alcohol consumption leads to lower survival rates, while with the abstention from alcohol an improvement in the exocrine function is to be expected $(19,20)$.
Complications requiring intervention occur in approximately $30-60 \%$ of patients (21). Generally, surgical or endoscopic intervention is indicated as soon as there is a suspicion of malignancy or the presence of therapy-resistant pain, for instance, as a result of stones in the pancreatic duct. Infected pancreatic pseudocysts, bile duct stenosis, gastric outlet obstruction or splenic vein thrombosis are also among the indications for surgery.

Persistent pain requiring analgesics may be treated using endoscopic and surgical procedures. A direct comparison of surgery and endoscopy shows an advantage for the surgical procedure over the longer term follow up (22). A plexus coeliacus blockade leads to a reduction in pain in around $50 \%$ of patients. The effect is, however, limited to several weeks. Very little data is available on thoracoscopic splanchnicectomy (23).

Symptomatic pancreatic pseudocysts should be treated regardless of their size. Surgical and endoscopic procedures are available. Surgical procedures more often lead to success, but are associated with a higher rate of lethality compared to endoscopic-guided drainage of pseudocysts into the duodenum or stomach. The success rate for endoscopic transgastric drainage is $65-95 \%$, with a low risk (about $10 \%$ ) of complications. Asymptomatic pancreatic pseudocysts that are larger than $5 \mathrm{~cm}$ and do not regress within six weeks should be treated since the risk of rupture, infection, icterus or bleeding increases (24).

Pancreatic duct stones can lead to obstruction of the pancreatic duct and, as a result, support pancreatic pseudocysts or fistulae, and cause pain episodes. Endoscopic therapy appears to be particularly suitable for treating solitary proximal stenosis, while surgical drainage procedures are superior for treating distal stenosis or in patients with chain of lakes (25).

Cholestasis caused by obstruction of the bile duct in the case of chronic pancreatitis can be treated by endoscopic stenting or surgical procedures. Surgery is particularly superior for treating distal bile duct stenosis with calcifying pancreatitis (25). 


\section{Surgical Procedures}

Surgical therapy for chronic pancreatitis is effective in treating therapy-resistant pain and local complications.

Long before the function of the pancreas was fully understood, Karl Gassenhauerhad already performed a marsupialization of a pancreatic cyst in 1882 (26). In the same year Friedrich Trendelenburg carried out the first distal pancreatectomy. In 1903 Theodor Kocher established a surgical procedure to mobilize the duodenum (27). Based on this, Walther Kausch performed a two-stage pancreatico-duodenectomy in 1909. As a first step, Kausch performed a cholecystojejunostomy and a side-to-side enterostomy. Six weeks later he resected the head of the pancreas with pylorus and partial duodenum. The remaining pancreatic tissue was anastomosed with the duodenum. This evolved to become known as the Whipple procedure still performed today (28). Karl Landsteiner's discovery of the blood groups and later pioneering of blood transfusion in 1914, along with the discovery of insulin by Frederick Banting in 1921, enabled radical progress in pancreatic surgery (29).

Since the 1960s, numerous surgical strategies, ranging from simple drainage procedure to total pancreatectomy, have been tested in practice as therapy for chronic pancreatitis.

In 1958 Puestow and Gilles first described opening the pancreatic duct by making a longitudinal incision, resecting the pancreatic tail and spleen and then reconstructing the pancreatic outflow via a latero lateral pancreatico-jejunostomy. The radical extent of the resection results in high morbidity. This technique was modified for this reason by Partington and Rochelle in 1960. Using this technique, which is still performed today, the pancreatic duct is opened in the pancreatic head and body and reconstructed using a Roux loop of jejunum. The tail of the pancreas and the spleen are left intact reducing the risk of endocrine and exocrine pancreatic insufficiency. The resulting decompression leads to lasting analgesia in $50-60 \%$ of patients $(30,31)$.

Besides the simple drainage procedures

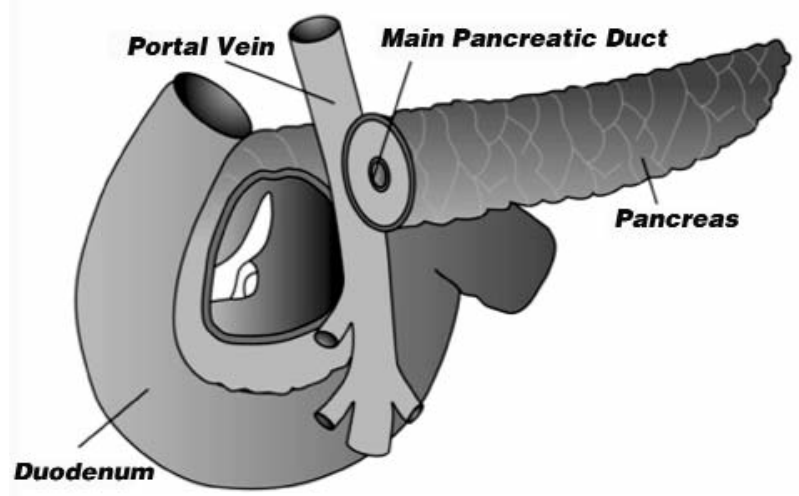

Figure 1. Beger procedure

modern resection techniques were established as alternative to the radical Whipple procedure. In 1972 duodenum preserving pancreatic head resections first began to play a role. The technique first described by Beger preserves the duodenum and thus the continuity of the gastroduodenal passage and the bile duct. The pancreas is transected above the portal vein and pancreatic head is subtotal resected. The remaining pancreatic parenchyma is drained via a jejunal loop using two anastomosis (to head and body in the same jejunal loop). Using Roux-en-Y reconstruction it is possible to restore the gastrointestinal passage (Fig. 1). The aim was to retain as much healthy parenchyma as possible while at the same time achieving decompression to control pain. After 5.7 years, $91.3 \%$ of the 388 patients included in the follow-up were pain-free $(32,33)$.

In 1985 Frey and Smith supplemented the procedure established by Beger with a longitudinal incision of the pancreatic duct (Partington-Rochelle) which was reconstructed by performing a longitudinal pancreaticojejunostomy (Frey procedure, Fig. 2). A narrow rim of the pancreatic head is preserved to prevent injury to the bile duct. The procedure has a lower mortality rate $(<1 \%)$ and less morbidity (9-39\%) than the Beger procedure without significant differences regarding pain, endocrine or exocrine functions $(34,35)$. A randomized controlled trail comparing the Frey procedure and the Beger procedure found no differences in terms of quality of life, pain 


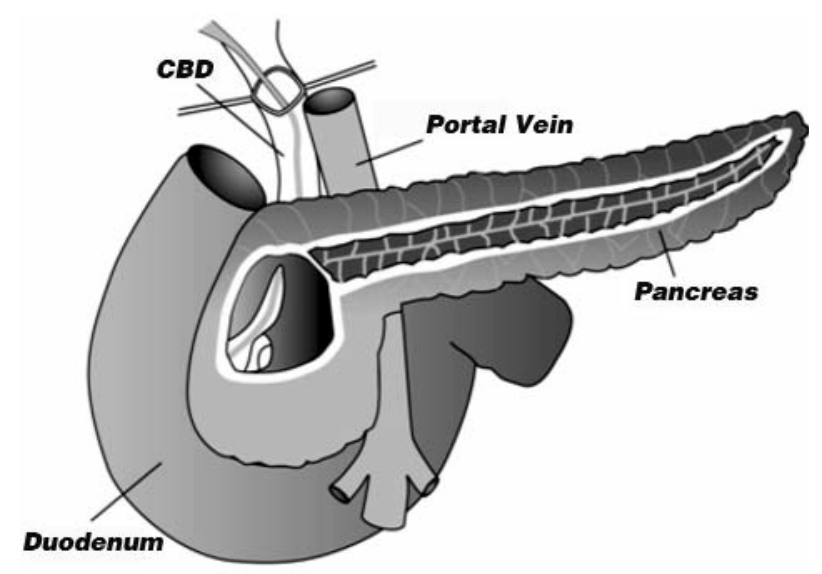

Figure 2. Frey procedure

control, or exocrine or endocrine insufficiencies. The mortality rate of the Beger procedure versus the Frey procedure was comparable with $39 \%$ and $34 \%$, respectively (36-39).

In another prospective study, the Frey procedure was compared to the Whipple procedure. The Frey procedure demonstrated itself to be superior in terms of quality of life and pain control in short term follow up and overall survival after 15 years. There were no significant differences regarding exocrine and endocrine insufficiency (40).

Further modifications of duodenum preserving pancreatic head resection include the Berne procedure and the Hamburg procedure which were introduced in 1998 (Fig. 3).

The Berne procedure combines the advantages of the Frey and Beger procedures. In contrast to the Beger procedure, a layer of pancreatic tissue is left on the anterior wall of the portal vein. Within the scope of one study, a mortality rate of $0 \%$ and low morbidity of $20 \%$ were achieved (41).

The Hamburg procedure was developed in 1998 by Izbicki et al. and is a modification of the Frey procedure to improve the outcome and pain control. Radical excision of the pancreatic head is performed and a longitudinal $\mathrm{v}$-shaped excision is madealong the pancreatic duct. This longitudinal incision can be adjusted to match the extent of the pathological changes. Reconstruction is achieved with side-to-side pancreaticojejunostomy (38).

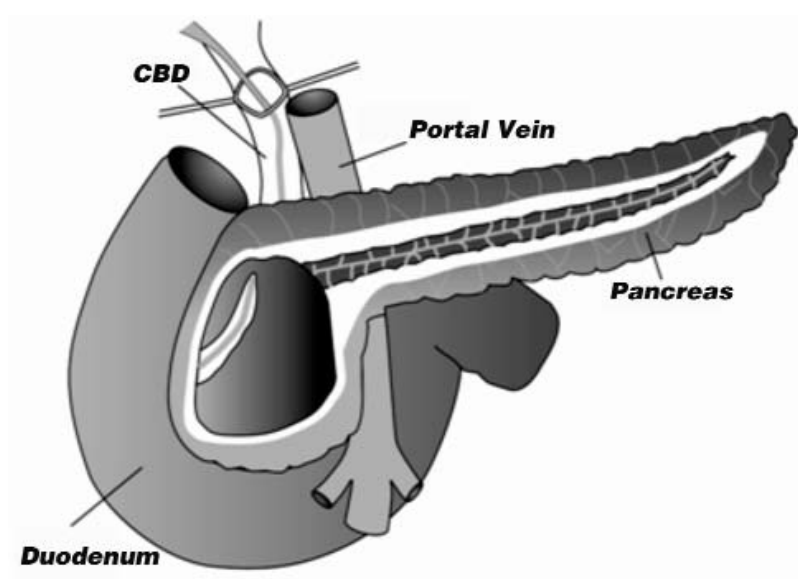

Figure 3. Hamburg procedure

\section{Gold Standard}

In more than $85 \%$ of patients the findings indicate inflammatory changes to the pancreatic head and an obstruction of the pancreatic duct (42). Resection is indicated in cases of inflammatory pseudotumors of the pancreatic head. The aim is to fully resect the inflamed parenchyma and preserve healthy parenchyma in respect to the residual exocrine and endocrine functions. The duodenum preserving pancreatic head resection is superior to the Kausch-Whipple procedure over short- and medium-term postoperative observational periods because the continuity of both the gastroduodenal passage and the bile duct is maintained. The different variations of duodenum preserving pancreatic head resection appear to be mainly equal to each other in terms of their therapeutic effectiveness (surgeries using the Berger, Frey, Berne, or Hamburg techniques) $(16,38,41)$.

In the case of an obstructed pancreatic duct (> $7 \mathrm{~mm}$ ) without detection of a pancreatic pseudotumor, as is the case in $10 \%$ of patients, it is possible to consider the application of a mere drainage procedure, such as the lateral pancreaticojejunostomy (Partington-Rochelle), whereby poorer long-term outcomes are to be expected when compared to duodenumpreserving pancreatic head resection (38). In case of small duct disease or chain or lakes the $\mathrm{V}$ shape excision of the ventral aspect of the pancreas (Izbicki procedure) is recommended. In 
the case of bile duct or gastric obstruction, a choledochojejunostomy or gastroenterostomy can be considered. Although DEPKR will treat alone probably, Hypersplensimusor recidivating variceal bleeding can be an indication for splenectomy.

\section{Outlook}

The safety of these procedures has been improved through consistent standardization of the perioperative management and specialization of the surgeons at centers focusing on pancreatic disease. Despite great progress in recent years regarding the management of complications, postoperative morbidity is high.

The optimal point in time for surgery is a controversial topic of discussion. Early surgical intervention may delay the progression of overall pancreatic insufficiency. The current multicenter ESCAPE trial is investigating if early surgical intervention benefits patients in terms of pain relief, endocrine and exocrine function, and quality of life.

Enhanced recovery after surgery (ERAS) protocols, or fast track protocols, aim to optimize pre- and post-operative management by standardizing aspects such as early mobilization, reintroduction of liquids and solids, achieving liquid balance, optimal analgesic therapy, drainage management and choice of antibiotics. Although randomized prospective multicenter trials have not been conducted, retrospective studies show a reduction of hospital stay and a possible reduction of postoperative morbidity (43).

The minimally invasive approach offers numerous benefits in comparison with open surgery, but these procedures can only be performed at highly specialized centers with very highly qualified surgeons. For the first time in 1994 Michael Wagner performed a laparoscopic pylorus preserving pancreatic head resection in a patient with chronic pancreatitis. In a retrospective study it was possible to show that this procedure is feasible and reduces length of hospital stay (44). There are no data on minimally invasive duodenum preserving pancreatic head resections.
The data available on a potential benefit of using robotic approaches for pancreaticoduodenectomyis extremely limited and the technical investments are enormous. Current studies indicate that the 30-day overall $\mathrm{com}^{-}$ plication rate is not significantly different than that for laparoscopic pancreaticoduodenectomy (44). Prospective randomized multicenter trials are needed.

\section{Conflict of Interest: none declared.}

\section{References}

1. Bornman PC, Botha JF, Ramos JM, Smith MD, Van der Merwe S, Watermeyer GA, et al. Guideline for the diagnosis and treatment of chronic pancreatitis. S Afr Med J. 2010;100(12 Pt 2):845-60.

2. Maisonneuve $P$, Lowenfels $A B$, Müllhaupt $B$, Cavallini $G$, Lankisch $P G$, Andersen JR, et al. Cigarette smoking accelerates progression of alcoholic chronic pancreatitis. Gut. 2005;54(4):510-4.

3. Weiss FU, Simon P, Bogdanova N, Mayerle J, Dworniczak B, Horst $J$, et al. Complete cystic fibrosis transmembrane conductance regulator gene sequencing in patients with idiopathic chronic pancreatitis and controls. Gut. 2005;54(10):1456-60.

4. Gress TM, Müller-Pillasch F, Lerch MM, Friess H, Büchler M, Beger $\mathrm{HG}$, et al. Balance of expression of genes coding for extracellular matrix proteins and extracellular matrix degrading proteases in chronic pancreatitis. Z Gastroenterol. 1994;32(4):221-5.

5. Masson E, Le Maréchal C, Delcenserie R, Chen JM, Férec C. Hereditary pancreatitis caused by a double gain-of-function trypsinogen mutation. Hum Genet. 2008;123(5):521-9.

6. Le Maréchal C, Masson E, Chen JM, Morel F, Ruszniewski P, Levy $P$, et al. Hereditary pancreatitis caused by triplication of the trypsinogen locus. Nat Genet. 2006;38(12):1372-4.

7. Braganza JM. The Pancreas: Biology, Pathobiology and Disease. Gut. 1994;35:431-2.

8. Gorry MC, Gabbaizedeh D, Furey W, Gates LK Jr, Preston RA, Aston $\mathrm{CE}$, et al. Mutations in the cationic trypsinogen gene are associated with recurrent acute and chronic pancreatitis. Gastroenterology. 1997;113(4):1063-8.

9. Toomey DP, Swan N, Torreggiani W, Conlon KC. Autoimmune pancreatitis. Br J Surg. 2007;94(9):1067-74.

10. Toomey DP, Swan N, Torreggiani W, Conlon KC.Autoimmune pancreatitis: medical and surgical management. JOP. 2007;8(3): 335-43.

11. Lowenfels AB, Maisonneuve P, DiMagno EP, Elitsur Y, Gates LK Jr, Perrault $\mathrm{J}$, et al. Hereditary pancreatitis and the risk of pancreatic cancer. International Hereditary Pancreatitis Study Group. J Natl Cancer Inst. 1997;89(6):442-6.

12. Lowenfels AB1, Sullivan T, Fiorianti J, Maisonneuve P. The epidemiology and impact of pancreatic diseases in the United States. Curr Gastroenterol Rep. 2005;7(2):90-5.

13. Strate T, Knoefel WT, Yekebas E, Izbicki JR. Chronic pancreatitis: etiology, pathogenesis, diagnosis, and treatment. Int J Colorectal Dis. 2003;18(2):97-106. Epub 2002 Sep 5.

14. Strate T, Yekebas E, Knoefel WT, Bloechle C, Izbicki JR. Pathogenesis and the natural course of chronic pancreatitis. Eur $\mathrm{J}$ Gastroenterol Hepatol. 2002;14(9):929-34.

15. DiMagno EP, Go VL, Summerskill WH. Relations between pancreatic enzyme outputs and malabsorption in severe pancreatic insufficiency. N Engl J Med. 1973;288(16):813-5. 
16. Bloechle C, Izbicki JR, Knoefel WT, Kuechler T, Broelsch CE. Quality of life in chronic pancreatitis--results after duodenum-preserving resection of the head of the pancreas. Pancreas. 1995;11(1):77-85.

17. Bojková M, Dítě P, Dvořáčková J, Novotný I, Floreánová K, Kianička B, Uvírová M, Martínek A. Immunoglobulin G4, autoimmune pancreatitis and pancreatic cancer. Dig Dis. 2015;33(1):86-90. doi: 10.1159/000368337. Epub 2014 Dec 17.

18. Chronic Pancreatitis German Society of Digestive and Metabolic Diseases (DGVS), Hoffmeister A, Mayerle J, Beglinger C, Büchler MW, Bufler P, et al. S3-Consensus guidelines on definition, etiology, diagnosis and medical, endoscopic and surgical management of chronic pancreatitis German Society of Digestive and Metabolic Diseases (DGVS) Z Gastroenterol. 2012:50(11):1176-224. doi: 10.1055/s-0032-1325479. German

19. Ammann RW, Akovbiantz A, Largiader F, Schueler G. Course and outcome of chronic pancreatitis. Longitudinal study of a mixed medical-surgical series of 245 patients. Gastroenterology. 1984; 86(5 Pt 1):820-8.

20. Lankisch PG, Löhr-Happe A, Otto J, Creutzfeldt W. Natural course in chronic pancreatitis. Pain, exocrine and endocrine pancreatic insufficiency and prognosis of the disease. Digestion. 1993:54(3): 148-55.

21. Knoefel WT, Eisenberger CF, Strate T, Izbicki JR. Optimizing surgical therapy for chronic pancreatitis. Pancreatology. 2002;2(4):379-84; discussion 385.

22. Díte P, Ruzicka M, Zboril V, Novotný I. A prospective, randomized trial comparing endoscopic and surgical therapy for chronic pancreatitis. Endoscopy. 2003;35(7):553-8.

23. Stefaniak T, Vingerhoets A, Makarewicz W, Kaska L, Kobiela J, Kwiecinska $B$, et al. Opioid use determines success of videothoracoscopic splanchnicectomy in chronic pancreatic pain patients Langenbecks Arch Surg. 2008;393(2):213-8. Epub 2007 Apr 14.

24. Gouyon B, Lévy P, Ruszniewski P, Zins M, Hammel P, Vilgrain V, et al. Predictive factors in the outcome of pseudocysts complicating alcoholic chronic pancreatitis. Gut. 1997;41(6):821-5.

25. Lerch MM, Bachmann KA, Izbicki JR. New guidelines on chronic pancreatitis: interdisciplinary treatment strategies. Chirurg. 2013; 84(2):99-105. German

26. Witzel 0. Aus der Klinik des Herrn Prof. Trendelenburg. Beiträge zur Chirurgie der Bauchorgane. Deutsche Zeitschrift für Chirurgie. 1886;24:326-54.

27. Payr E. Die Mobilisierung des Duodenum nach Kocher zur Entfernung retroduodenal liegender Choledochussteine. Deutsche Zeitschrift für Chirurgie. 1904;75:1-13.

28. Whipple AO, Parsons WB, Mullins CR. Treatment of carcinoma of the ampulla of vater. Ann Surg. 1935;102(4):763-79.

29. Howland G. Dysinsulinism. J Am Med Association. 1929;93: 674.

30. Duval MK Jr. Caudal pancreatico-jejunostomy for chronic relapsing pancreatitis. Ann Surg. 1954;140(6):775-85.

31. Partington PF, Rochelle RE. Modified Puestow procedure for retro- grade drainage of the pancreatic duct. Ann Surg. 1960;152:1037-43. 32. Ryder NM, Reber HA. Pancreatic surgery. Curr Opin Gastroenterol. 2000;16(5):426-30.

33. Duffy JP, Delano MJ, Reber HA. Pancreatic surgery. Curr Opin Gastroenterol. 2002;18(5):568-73.

34. Pessaux P, Kianmanesh R, Regimbeau JM, Sastre B, Delcenserie R, Sielezneff I, et al. Frey procedure in the treatment of chronic pancreatitis: short-term results. Pancreas. 2006;33(4):354-8.

35. Izbicki JR, Bloechle C, Broering DC, Knoefel WT, Kuechler T, Broelsch $\mathrm{CE}$. Extended drainage versus resection in surgery for chronic pancreatitis: a prospective randomized trial comparing the longitudinal pancreaticojejunostomy combined with local pancreatic head excision with the pylorus-preserving pancreatoduodenectomy. Ann Surg. 1998; 228(6):771-9.

36. Bachmann K, Tomkoetter L, Erbes J, Hofmann B, Reeh M, Perez D, et al. Beger and Frey procedures for treatment of chronic pancreatitis: comparison of outcomes at 16-year follow-up. J Am Coll Surg. 2014;219(2):208-16.

37. Izbicki JR, Knoefel WT, Bloechle C, Küchler T, Kühn R, Limmer JC, et al. The status of duodenum-preserving resection of the head of the pancreas in therapy of chronic pancreatitis. Zentralbl Chir. 1995;120(4):298-305. German

38. Izbicki JR, Bloechle C, Knoefel WT, Kuechler T, Binmoeller KF, Broelsch CE. Duodenum-preserving resection of the head of the pancreas in chronic pancreatitis. A prospective, randomized trial. Ann Surg. 1995;221(4):350-8.

39. Strate T, Taherpour Z, Bloechle C, Mann O, Bruhn JP, Schneider C, et al. Long-term follow-up of a randomized trial comparing the beger and frey procedures for patients suffering from chronic pancreatitis. Ann Surg. 2005;241(4):591-8.

40. Bachmann K, Tomkoetter L, Kutup A, Erbes J, Vashist Y, Mann O, et al. Is the Whipple procedure harmful for long-term outcome in treatment of chronic pancreatitis? 15-years follow-up comparing the outcome after pylorus-preserving pancreatoduodenectomy and Frey procedure in chronic pancreatitis. Ann Surg. 2013;258(5): 815-20; discussion 820-1.

41. Köninger J, Seiler CM, Sauerland S, Wente MN, Reidel MA, Müller MW, et al. Duodenum-preserving pancreatic head resection--a randomized controlled trial comparing the original Beger procedure with the Berne modification (ISRCTN No. 50638764). Surgery. 2008;143(4):490-8. doi: 10.1016/j.surg.2007.12.002.

42. Traverso LW, Tompkins RK, Urrea PT, Longmire WP Jr. Surgical treatment of chronic pancreatitis. Twenty-two years' experience. Ann Surg. 1979;190(3):312-9.

43. Barton JG. Enhanced recovery pathways in pancreatic surgery. Surg Clin North Am. 2016;96(6):1301-1312.

44. Lianos GD, Christodoulou DK, Katsanos KH, Katsios C, Glantzounis GK. Minimally invasive surgical approaches for pancreatic adenocarcinoma: recent trends. J Gastrointest Cancer. 2017;48(2):129-134. 